\title{
SYTUACJA PANDEMII A DOSTĘP DO EDUKACJI UCZNIA ZE SPEKTRUM AUTYZMU
}

\section{Wprowadzenie}

Celem artykułu jest ukazanie sytuacji społeczno-edukacyjnej ucznia ze spektrum autyzmu w czasie sytuacji pandemii. Pandemia odcisnęła istotny ślad w procesie edukacji, ponieważ w marcu 2020 r. nauczyciele musieli zmierzyć się z prowadzeniem nauczania zdalnego, zaś rodzice i uczniowie z samodzielną realizacją zajęć. Dlatego też zamknięcie szkól, jak i placówek oświatowych, przyczyniło się do nierówności społecznej pod względem dostępności do usług terapeutycznych i edukacyjnych. Przejście na tryb zdalny spowodowało, że znaczna liczba uczniów ma problem $\mathrm{z}$ dostępem do Internetu, czy też zmierzeniem się z nowymi technologiami. W bardzo trudnej sytuacji są osoby o specjalnych potrzebach rozwojowych i edukacyjnych, np. dzieci ze spektrum autyzmu (Plichta, 2020, s. 71). Edukacja w czasie pandemii i totalnej izolacji społecznej zmieniła się w Polsce diametralnie, „stawiając przed osobami zarządzającymi szkołami, nauczycielami, a przede wszystkim uczniami i ich rodzinami nowe wyzwania. Te ostatnie możemy rozumieć zarówno jako spore, budzące złe emocje zagrożenie, ale także jako szansę" (Pyżalski, 2020, s. 2). Wielu rodziców zmierza się z trudem edukacji dzieci ze spektrum autyzmu, stając się w jednej chwili zarówno pedagogiem, jak i rodzicem. Całodobowy kontakt $\mathrm{z}$ dzieckiem o specjalnych potrzebach rozwojowych i edukacyjnych bez możliwości odpoczynku staje się dla rodziców dużym wyzwaniem, a dziecko ogranicza tylko i wyłącznie do kontaktu z osobą dorosłą, co negatywnie wpływa na jego rozwój. Warto dodać, że wiele rodzin jest w trudnej sytuacji ekonomicznej, ponieważ ponoszą dodatkowe koszty związane z rehabilitacją czy też terapią. Rodzice bardzo często próbują prywatnie zorganizować zajęcia czy warsztaty dla swoich dzieci. Edukacja zdalna jest dużym wyzwaniem zarówno dla rodziców, uczniów, 
a przede wszystkim nauczycieli, terapeutów, którzy nie mają możliwości bezpośredniego kontaktu z podopiecznymi, co do tej pory było podstawą działań terapeutycznych (Pachowicz, 2020, s. 119).

Problematyka dotycząca spektrum autyzmu w dzisiejszych czasach jest bardzo ważna, ponieważ coraz częściej spotykamy się z tym zaburzeniem. Nasza wiedza na ten temat jest głębsza i bardziej powszechna. Warto także dodać, iż w ostatnich latach do szkół ogólnodostępnych coraz częściej trafiają dzieci, które posiadają orzeczenie o potrzebie kształcenia specjalnego. Realizują one program nauczania razem z rówieśnikami w klasie lub są objęte specjalnym programem nauczania dostosowanym do ich potrzeb oraz umiejętności. Jedna jak i druga forma kształcenia wymaga od nauczycieli odpowiedniego przygotowania, a także wysiłku, aby sprostać wymaganiom uczniów.

Uczeń ze spektrum autyzmu w szkole ogólnodostępnej to duże wyzwanie dla rodziców i nauczycieli. Taki uczeń jest bardzo wymagający, boryka się z trudnościami, ale też wykazuje wybitne zdolności, które należy rozwijać. Zanim przejdę do dalszej części artykułu, w skrócie przybliżę, czym jest spektrum autyzmu.

Autyzm ma związek ze szczególnym zaburzeniem funkcji mózgu. Jego źródłem może być wada genetyczna, uraz mózgu lub jego choroba. Dlatego też warto dodać, iż autyzm stanowi zaburzenie rozwojowe, a jego zachowanie zmienia się wraz z wiekiem i zdolnościami dziecka. Jego główną cechą we wszystkich stadiach rozwoju oraz w różnych poziomach zdolności jest upośledzenie socjalizacji, wyobraźni, a także komunikacji (Frith, 2005, s. 7-10). Zaburzenie w relacjach społecznych u dzieci ze spektrum autyzmu można zauważyć bardzo wcześnie. Niektóre jego symptomy możemy dostrzec w rozwoju, zanim dziecko uzyska diagnozę dotyczącą autyzmu. Pierwsze takie więzi społeczne dziecka występują w czasie kontaktu z matką, dlatego też takie relacje są istotnym sygnałem zapowiadającym rozwój autyzmu (Jaklewicz, 2000, s. 118). Badania, które dotyczą pierwszych interakcji matka - dziecko ukazują, iż zdrowy noworodek posiada umiejętność dostrajania się do sytuacji społecznych w zakresie naśladowania, a także poszukiwania kontaktu wzrokowego, słysząc głos matki. Natomiast około 6. tygodnia życia pojawia się tzw. uśmiech społeczny, a w 6-8 miesiącu dziecko jest w stanie odróżnić twarze osób bliskich, zaś na obce osoby reaguje lękiem (Jagielska, 2009, s. 36). Z obserwacji rodziców wynika, iż w pierwszych miesiącach życia dziecka niepokoi ich, iż dziecko nie okazuje uczuć w stosunku do matki i opiekunów. Dziecko wykazuje słaby kontakt wzrokowy, brak mimiki twarzy, a także niechęć wzięcia na ręce (Wing, 2005, s. 117). Pragnie przede wszystkim samotności oraz nie jest zainteresowane kontaktem fizycznym $z$ inną osobą, a także zachowuje się tak, jakby członkowie jego rodziny byli poza obszarem jego zainteresowania (Pisula, 2011, s. 449). 
W związku z tym, w pierwszym roku życia dziecka nie jesteśmy w stanie do końca określić nieprawidłowości w zachowaniu, które są specyficzne dla autyzmu. Natomiast nie oznacza to, że nie są zauważane żadne nieprawidłowości oraz że nie zostaną one dostrzeżone w późniejszym wieku. Warto dodać, iż opóźnienie rozwoju często ma związek z autyzmem, ale pojawia się ono także u dzieci z niepełnosprawnością intelektualną, u których autyzm nie występuje. Do pierwszych objawów autyzmu można zaliczyć brak wskazywania oraz spojrzeń w odniesieniu do drugiej osoby. Istotne jest również to, iż takie objawy mogą sugerować autyzm, ale odnoszą się także do dzieci z niepełnosprawnością intelektualną, u których nie stwierdzono autyzmu. Dlatego diagnozę odnośnie autyzmu warto postawić najlepiej do ukończenia trzeciego-czwartego roku życia dziecka.

Należy zauważyć, że istnieją podtypy autyzmu, jednym z nich jest zespół Aspergera (obecnie nazywany spektrum zaburzeń autystycznych). Jest on „lizejszą” formą autyzmu, dlatego też zazwyczaj bywa tak, iż takie dzieci w piątym roku życia mówią płynnie, nawet jeśli ich rozwój języka zaczął się późno. U niektórych dzieci pomimo występowania wczesnych objawów autystycznych dochodzi do olbrzymiej poprawy. W zależności od wieku dziecka, ich zainteresowanie ludźmi staje się dość duże, co wiąże się z tym, iż dystans do drugiego człowieka staje się mniejszy. Pomimo tego faktu i tak stają się one niezdolne do społecznych interakcji, a także kontaktów międzyludzkich (Frith, 2005, s. 7-10). Wraz z rozwojem, u dziecka pojawiają się pojawiają się nowe objawy zaburzeń w obszarze komunikacji, a także rozumieniu emocji, ich wyrażaniu oraz nawiązywaniu relacji społecznych (Pisula, 2000, s. 117). Rodzice/opiekunowie tych dzieci najczęściej sygnalizują następujące zachowania:

- brak nawiązania relacji z członkami rodziny,

- brak spontanicznego powitania z rodzicem i członkami rodziny,

- słabo albo w sposób nieodpowiedni wyraża emocje, a także rzadko dzieli z nimi swoje emocje,

- nie jest w stanie posługiwać się gestami w celu nawiązania kontaktów społecznych,

- zaburzona mimika twarzy,

- podchodzi zbyt blisko i ucieka daleko od osób ze swojego najbliższego towarzystwa,

- nie umie inicjować zabawy zabawkami, natomiast instruowany przez rodzica jest w stanie bawić się prostymi przedmiotami, fragmentami zabawek itp. (Greenspan, Wieder, 2014 s. 28),

- posiada ograniczoną zdolność naśladowania oraz nie uczestniczy w zabawach z udawaniem z innymi dziećmi,

- występują u takiego dziecka rutynowe wzorce, brak pomysłowości i wyobraźni w czasie zabawy, 
- unika kontaktów z rówieśnikami (Pisula, 2000, s. 118; Pisula, 2011, s. 447),

- nie jest w stanie wykorzystać zachowań niewerbalnych (mimika, gestykulacja, kontakt wzrokowy, postawa ciała) do kontaktów społecznych (Pisula, 2011 s. 447),

- nie szuka pocieszenia zarówno u rodziców jak i dziadków, rodzeństwa,

- nie posiada wyobraźni społecznej, a także nie odwzajemnia relacji społecznych (Cotugno, 2011, s. 45).

Liczba dzieci ze spektrum zaburzeń autystycznych (mowa tutaj także o zespole Aspergera) z roku na rok ciągle rośnie. W związku z problemem w porozumiewaniu się, sposobem przetwarzania informacji oraz rozwoju społecznym, dzieci, a także młodzież, stanowią istotny problem dla systemu oświaty. Warto w tym momencie przytoczyć słowa jednej z matek: „pragnęłabym takiej szkoły, w której mógłby być sobą, w której nie dokuczano by mu z powodu, że jest inny i gdzie by go zrozumiano. Lecz przede wszystkim pragnęłam szkoły, gdzie cierpliwie pracowano by, aby do niego dotrzeć. Największym naszym zmartwieniem było, że gdyby jego edukacja nie powiodła się, nie byłby w stanie żyć samodzielnie, gdy się zestarzejemy lub gdy opuścimy ten świat" (Baron-Cohen, Bolton, 1997, s. 65). Dlatego też istotnym problemem dla rodzica jest wybranie odpowiedniej szkoły dla swojego dziecka, która jest otwarta na poszukiwanie coraz to nowszych metod pracy z dziećmi ze spektrum autyzmu. Bardzo ważnym problemem na początku edukacji dla dziecka ze spektrum autyzmu jest pokonanie oporu w sobie. Taki opór wynika przede wszystkim z problemu adaptacji w nowym środowisku. Czasami również dzieci ze spektrum autyzmu mają trudności w integracji ze środowiskiem, ponieważ niekiedy zachowują się agresywnie czy też są nadwrażliwe na bodźce zapachowe, dotykowe, słuchowe, wzrokowe oraz mają problemy z koncentracją uwagi. Większość zachowań tych dzieci jest dla społeczeństwa niezrozumiała. Brak jakichkolwiek informacji dotyczących dzieci ze spektrum autyzmu może przede wszystkim ograniczyć dalszą edukację oraz integrację z rówieśnikami (Baron-Cohen, Bolton, 1997, s. 69). W każdym zespole klasowym mają styczność ze sobą różne osobowości oraz indywidualności. Dlatego też celem nauczyciela, jak i całej grupy, jest budowanie takiego klimatu społecznego, który pozwoli dziecku ze spektrum autyzmu czuć się dobrze, a także będzie mogło ono liczyć na pomocy rówieśników z klasy (Pyzikiewicz, 2016, s. 45). Istotną kwestią w systemie edukacji dla dzieci autystycznych jest to, iż mogą one uczęszczać do szkoły ogólnodostępnej, natomiast ich proces nauczania jest indywidualnie dostosowany do każdego dziecka. Warto również pamiętać, iż zespół pracujący z dzieckiem mającym orzeczenie o potrzebie kształcenia specjalnego tworzą zarówno nauczyciela, jak i specjaliści prowadzący zajęcia (nauczyciel przedmiotu, nauczyciel wspomagający, pedagog szkolny, psycholog, logopeda itd.). Osobę, która jest koordynatorem pracy zespo- 
łu wskazuje dyrektor, najczęściej jest to wychowawca. Członkowie zespołu mają za zadanie m.in. opracować Indywidualny Program Edukacyjno-Terapeutyczny (IPET) (Pyzikiewicz, 2016, s. 29). Dlatego też nauczyciele i wychowawcy powinni być świadomi, że praca z dzieckiem ze spektrum autyzmu wymaga dodatkowych działań, by dziecko przyswoiło wiedzę w typowej klasie szkolnej (Bowen, Plimpey, https://polskiautyzm.pl/srodowisko-przyjazne-dzieciom-ze-spektrum-autyzmu/).

Najważniejsze natomiast jest, iż nauczyciel, który posiada ucznia autystycznego w klasie, powinien pokierować jego kształceniem. Uczeń ze spektrum autyzmu najczęściej zajmuje miejsce w pierwszej ławce, aby móc skoncentrować uwagę na nauczycielu. Ważne jest również to, aby nauczyciel tworzył takie materiały by dziecko ze spektrum autyzmu mogło je lepiej przyswoić, np. do tekstu należy dodać zdjęcia, rysunki itp. Bardzo istotne jest również prowadzenie dodatkowych zajęć pozalekcyjnych, indywidualnych z dzieckiem, np. zajęcia rewalidacyjne, logopedyczne, terapeutyczne. W klasie, do której uczęszcza dziecko autystyczne, musi być zatrudniony drugi nauczyciel - wspomagający. Trudności dziecka z autyzmem w klasie mogą dotyczyć przede wszystkim kontaktów społecznych oraz akceptacji zasad panujących w grupie:

- problem z utrzymaniem i nawiązaniem relacji, brak kontaktu wzrokowego,

- brak rozumienia oczekiwań otoczenia,

- nie jest w stanie domyślić się intencji na podstawie gestów,

- agresywna reakcja na zmianę rutynowej sytuacji,

- trudności z rozpoznaniem oraz nazywaniem właściwych emocji innych osób (Wujec-Kaczmarek, https://www.slideshare.net/alicjawk/ucze-autystyczny-w-zespole-klasowym)/.

Dlatego też dzieci ze spektrum autyzmu potrzebują zarówno uwagi, jak i akceptacji. Obecność „specjalnych” dzieci w klasie uczy dzieci „zdrowe” umiejętności społecznych, których nie jesteśmy w stanie przekazać poprzez teorię (Korulska, 2013, s. 166). W czasie nauczania dziecka ze spektrum autyzmu mogą pojawić się następujące kategorie problemów:

1. Zaburzenia komunikacji werbalnej i niewerbalnej z uczniem - w pracy nauczyciela istotne jest, aby był w stanie rozpoznać wysyłane do niego przez uczniów sygnały, a także dostosować tempo oraz sposób materiału dydaktycznego, by uczeń go rozumiał. Pedagog powinien również mówić w taki sposób, aby dziecko autystyczne rozumiało treści i polecenia do zadań. Powinien być przygotowany na poświęcenie dodatkowego czasu, jeżeli dziecko czegoś nie jest w stanie zrozumieć za pierwszym razem.

2. Zaburzenia emocjonalne, społeczne - pedagog, który nie posiada doświadczenia do pracy z dziećmi „specjalnymi” wykazuje sceptyczne podejście do włączenia ich do swojej klasy. Nieprzywidywalność zachowania jest także czynnikiem 
stresującym dla nauczyciela, gdyż nie jest w stanie określić, jak dziecko ze spektrum autyzmu zareaguje w danej sytuacji względem jego czy też rówieśników w klasie. Dlatego też bardzo ważne jest, aby szkoła była przystosowana do kształcenia uczniów o zróżnicowanych potrzebach edukacyjnych oraz możliwościach psychofizycznych (Antonik, 2015, s. 157-158). Dobrym pomysłem jest także integracja dzieci ze spektrum autyzmu z rówieśnikami z zespołu klasowego przy pomocy kółek przedmiotowych: plastycznych, teatralnych itd. W mniejszym gronie i w swobodnej atmosferze można zachęcić ich do współpracy.

\section{Opis przypadku}

W celu rozpoznania sytuacji uczniów z autyzmem podjęłam działania o charakterze diagnostycznym, aby uzyskać obraz funkcjonowania ucznia z autyzmem, realizującego obowiązek nauki w szkole ogólnokształcącej podczas pandemii. Aby rozpoznać sytuację edukacyjną i terapeutyczną przeprowadziłam wywiad z matką dziecka $\mathrm{z}$ autyzmem oraz obserwację ucznia w warunkach zdalnej edukacji. Ponadto zapoznałam się z orzeczeniem ucznia i wskazaniami do pracy dydaktyczno-terapeutycznej z nim. Trud diagnozy podjęłam dla uzyskania odpowiedzi na pytanie: W jaki sposób funkcjonuje uczeń z autyzmem w czasie pandemii? oraz: Jakie zagrożenia dla ucznia z autyzmem niesie izolacja społeczna i zdalne nauczanie?

W toku diagnozy otrzymałam materiał empiryczny opracowany na potrzeby niniejszego artykułu w narracji odpowiadającej postawionym pytaniom.

Marcin ma 11 lat, uczęszcza do szkoły publicznej. Spektrum autyzmu zostało u niego zdiagnozowane w 2016 roku. Pierwsze objawy związane z autyzmem dostrzegła mama. Po jakimś czasie wychowawczyni z klasy również zauważyła, że chłopiec nie zachowuje się jak reszta jego rówieśników. Z jej obserwacji wynikało, że chłopiec przejawia niektóre symptomy autystyczne. Chłopiec niczym się nie interesował, nie wykonywał żadnych poleceń, nie siedział w ławce, leżał na sofie lub chodził po klasie, często krzyczał i wpadał w histerię. O zaistniałej sytuacji poinformowała mamę ucznia i pokierowała ją, jakie ma wykonać dalsze kroki w sprawie zdiagnozowania chłopca. Po otrzymaniu orzeczenia zalecono, aby Marcin był pod stałą kontrolą w poradni zdrowia psychicznego. Raz w tygodniu odbywały się spotkania ze specjalistą jeszcze przed obecną pandemią. Niestety, w chwili obecnej takie wizyty odbywają się sporadycznie i są często odwoływane. Warto dodać, iż dziecko uczęszczało raz w tygodniu na terapię psychologiczną w szkole, dzięki której uczyło się konstruktywnego wyrażania trudnych emocji, jak i teorii umysłu. W czasie tych zajęć w szczególności prowadzony był trening umiejętności społecznych, co miało na celu przede wszystkim nabywanie i rozwijanie umiejętności społecznych. Takie 
zajęcia odbywały się grupowo. Terapeuta w czasie tych zajęć pokazywał na właściwych przykładach, jak należy się zachowywać i postępować w różnych sytuacjach społecznych. Chłopiec bardzo lubił uczęszczać na te terapie, ponieważ mógł spotykać się ze swoimi rówieśnikami. Jak stwierdziła mama chłopca, zajęcia związane z rozwijaniem umiejętności społecznych pomagały Marcinowi przede wszystkim w: korygowaniu nieprawidłowych nawyków i zastąpieniu ich adekwatnymi do sytuacji, uzyskaniu umiejętności i wiedzy społecznej, a co najważniejsze, przełożeniu wyuczonych oraz wyćwiczonych zachowań. Niestety, w obecnej sytuacji w związku z ograniczeniami wynikającymi z pandemii, zajęcia nie odbywały się wcale, zaś negatywne skutki braku kontaktu zarówno z terapeutą, jak i rówieśnikami odczuwa uczeń. Chłopiec stał się niespokojny, rozdrażniony i nie wykazuje dużej chęci kontaktu ze swoim młodszym rodzeństwem. Podobne konsekwencje braku udziału w innych formach terapii odczuwa Marcin, w tym brak systematycznego udziału w zajęciach sensorycznych. W trakcie tych zajęć Marcin uczył się odpowiedniego reagowania na bodźce, zaś dzięki odpowiednio dobranym ćwiczeniom mógł poprawiać swoją motorykę, koordynację ruchową oraz koncentrację uwagi. Pomimo wysłanych mailowo zajęć, ćwiczeń, chłopiec nie wykazuje chęci ich wykonywania, ponieważ zajęcia nie są tak interesujące jak przeprowadzone przez terapeutę. $\mathrm{Z}$ obserwacji mamy wynika, że jeszcze większe deficyty w czasie pandemii wystąpiły u Marcina w sferze zarówno emocjonalnej, jak i społecznej. Bardzo często zdarza mu się reagować nieadekwatnie do sytuacji i na wyrost, często się irytuje i dyskutuje. Dziecko uczęszczając do szkoły osiągało dosyć wysokie wyniki w nauce z zakresu matematyki i języków. W trakcie pandemii nie jest zainteresowany nauką, ponieważ uważa, że rodzice nie są jego nauczycielami i prowadzone przez nich zajęcia nie są tak interesujące jak w szkole. Marcin nie jest w stanie przestawić się na tryb zdalny, ponieważ nie traktuje tego typu nauki poważnie. Jego dotychczasowe osiągnięcia uległy znacznemu obniżeniu. Kontakt z kolegami z klasy odbywa się tylko za pośrednictwem różnych portali społecznościowych, co nie do końca odpowiada chłopcu. Warto również dodać, iż zainteresowanie kadry pedagogicznej w czasie trwania pandemii jest sporadyczne. Nauczyciele wysyłają chłopcu zadania do wykonania, które niekiedy są trudne do wykonania i czasochłonne. To na rodzicach spoczywa trud, aby dziecku pomóc, jeżeli nie jest w stanie sam tego wykonać. Podsumowując: zdaniem mamy Marcina istniejąca pandemia wpłynęła negatywnie na rozwój, edukację oraz kontakty z rówieśnikami. Trudności dzieci ze spektrum autyzmu w czasie pandemii są niezauważalne, a wszelki trud, aby dziecko nie utraciło dotychczas osiągniętych umiejętności, spoczywa na rodzicach czy opiekunach. Rodzice oczekują, aby Marcin:

- miał stały i systematyczny kontakt ze swoimi nauczycielami, terapeutami,

- zajęcia prowadzone zdalnie nie były przeładowane treściami, 
- lekcje prowadzone były indywidualnie z uczniem, ponieważ dziecko rozprasza się, nie skupia uwagi na przekazywanych wiadomościach, widząc swoich rówieśników na ekranie monitora,

- pomiędzy prowadzonymi lekcjami ustalane były dłuższe przerwy, aby uczeń mógł wyciszyć się i odpocząć,

- lekcje uwzględniały potrzeby i umiejętności dziecka, były interesujące. Oczekiwania chłopca:

- miał możliwość w trakcie zajęć porozmawiać ze swoimi rówieśnikami,

- kontakt z nauczycielami i terapeutami był cykliczny,

- zajęcia były prowadzone w sposób interesujący, schematyczny.

\section{Zakończenie i wnioski końcowe}

Podsumowując, dzieci ze spektrum autyzmu w szkole masowej wymagają od nauczycieli szczególnej uwagi oraz zrozumienia w różnych sytuacjach, które mogą pojawić się w czasie lekcji. Izolacja przymusowa to przede wszystkim trudny czas zarówno dla dzieci ze spektrum autyzmu, jak i rodziców. $Z$ powodu pandemii utraciły one możliwość udziału w rehabilitacji, leczeniu czy też edukacji. Dla dzieci ze spektrum autyzmu szkoła staje się drugim domem, gdyż w niej czują się spokojne, pewne oraz bezpieczne. Niestety, obecna sytuacja związana z pandemią zaburzyła spokój i harmonię, ponieważ lekcje, które w przypadku dzieci autystycznych powinny odbywać się stacjonarnie, zostały zamienione na zajęcia przez Internet.

Dziecko ze spektrum autyzmu w czasie pandemii ma ograniczony dostęp zarówno do bezpośredniej edukacji, kontaktu z nauczycielem, jak i terapii logopedycznej, psychologicznej, fizjoterapii, zajęć z zakresu integracji sensorycznej itp. Skutkiem takiej sytuacji może być:

- nieradzenie sobie z emocjami negatywnymi (dziecko częściej wpada w złość, niecierpliwi się, przejawia zachowania agresywne),

- dziecko ze spektrum autyzmu jest przebodźcowane, siedzi przed monitorem komputera po 5-6 godzin,

- ograniczenie możliwości wymagań zawartych w podstawie programowej co może mieć negatywny skutek na rozwój dziecka, a także jego dotychczasowe osiagnięcia.

- gorsze efekty kształcenia.

Aby niwelować skutki izolacji, nauczyciele czy też terapeuci w czasie pandemii powinni:

- organizować zajęcia, grupy wsparcia, aby dziecko miało kontakt z rówieśnikami, umożliwić im wysyłanie zdjęć, aby uczeń mógł dzielić się swoimi przemyśleniami i opowieściami, 
- dobrać, dostosować odpowiednie, indywidualne metody pracy w zależności od umiejętności wychowanka, pomimo izolacji i pracy zdalnej,

- szkoły powinny dostosowywać swoje działania tak, by w żaden sposób nie pogłębiać nierówności edukacyjnych między uczniami neurotypowymi i tymi o szczególnych potrzebach edukacyjnych,

- nagrywać zajęcia z terapeutami, aby dziecko mogło ćwiczyć w domu razem z rodzicem,

- ustalić wspólnie program terapeutyczno-edukacyjny realizowany w taki sam sposób w szkole i w domu,

- prowadzić cykliczne konsultacje z rodzicami, terapeutami i nauczycielami.

Dla ucznia ze spektrum autyzmu bardzo ważna jest relacja z rówieśnikami, ponieważ to relacje społeczne i emocjonalne sprawiają takiemu dziecku największe trudności w funkcjonowaniu. Uczeń ze spektrum autyzmu wymaga ciągłego kontaktu z terapeutami, którzy prowadzą zajęcia zarówno indywidualne, jak i grupowe. Sporadyczne spotkania lub ich brak może być skutkiem tego, że dziecko zapomni, czego się do tej pory nauczyło. Niestety, w czasie pandemii dochodziło do takich sytuacji, gdzie dzieci ze spektrum autyzmu nie miały możliwości uczestnictwa w terapii, udziału w systematycznych zajęciach bezpośrednio ze specjalistą. Sytuacja pandemii wpływa negatywnie zarówno na rozwój, jak i edukację dziecka autystycznego.

\section{Bibliografia}

Antonik A. (2015). Nauczyciel wobec trudności zwiąanych z edukacją uczniów ze spektrum autyzmu w warunkach szkoty integracyjnej i ogólnodostępnej. Analiza obszarów problemowych. Poznań: Uniwersytet im. A. Mickiewicza w Poznaniu.

Cotugno A.J. (2011). Terapia grupowa dla dzieci z zaburzeniami ze spectrum autyzmu. Rozwijanie kompetencji i umiejętności spotecznych. Warszawa: Wydawnictwo Fraszka Edukacyjna.

Baron-Cohen S., Bolton P. (1997). Autyzm Fakty. Kraków: Krajowe Towarzystwo Autyzmu.

Frith U. (2005). Autyzm i zespót Aspergera. Warszawa: Państwowy Zakład Wydawnictw Lekarskich.

Greenspan S.L., Wieder S. (2014). Dotrzeć do dziecka z autyzmem. Jak pomóc dzieciom nawiazzywać relacje, komunikować się i myśleć. Metoda Floortime. Kraków: Wydawnictwo Uniwersytetu Jagiellońskiego.

Jagielska G. (2009). Objawy autyzmu dziecięcego. W: J. Komender, G. Jagielska, A. Bryńska (red.), Autyzm i zespót Aspergera. Warszawa: Wydawnictwo Lekarskie 
PZWL.

Jaklewicz H. (2000). Autyzm dziecięcy. W: A. Popielarska, M. Popielarska (red.), Psychologia wieku rozwojowego. Warszawa: Wydawnictwo Lekarskie PZWL.

Korulska E. (2013). Funkcjonowanie dzieci z autyzmem w warunkach szkoty ogólnodostępnej, czyli integracja w szkole nieintegracyjnej. „Konteksty Pedagogiczne”, nr 1.

Pachowicz M. (2020). Edukacja i terapia osób z niepetnosprawnościa w czasie pandemii COVID-19 na przyktadzie Ośrodka Rewalidacyjno-Edukacyjno-Wychowawczego. „Parezja”, nr 2(14).

Pisula E. (2011). Wspomaganie osób z zaburzeniami należacymi do autystycznego spektrum w perspektywie psychopatologii rozwojowej. W: J. Trempała, Psychologia rozwojowa cztowieka. Warszawa: PWN.

Pisula E. (2000). Autyzm u dzieci. Diagnoza, klasyfikacja, etiologia. Warszawa: PWN.

Plichta P. (2020). Różne konteksty nierówności cyfrowych a wyzwania dla zdalnej edukacji - propozycje rozwiąań. W: J. Pyżalski (red.), Edukacja w czasach pandemii wirusa COVID-19. Z dystansem o tym, co robimy obecnie jako nauczyciele. Warszawa: Edukacja. (e-book).

Pyzikiewicz A. (2016). Wespót w zespót-organizacja pracy. W: R. Cybulska, J. Dryjańska, K. Gotlin, M. Kłoda, K. Pomorska, A. Pyzikiewicz, Uczeń z zespotem Aspergera w szkole ogólnodostępnej. Warszawa: Ośrodek Rozwoju Edukacji.

Pyżalski J. (2020). Wstęp. W: J. Pyżalski (red.), Edukacja w czasach pandemii wirusa COVID-19. $Z$ dystansem o tym, co robimy obecnie jako nauczyciele. Warszawa: Edukacja. (e-book).

Wing L. (2005). Związek między zespotom Aspergera $i$ autyzmem Kannera. W: U. Frith (red.), Autyzm i zespót Aspergera. Warszawa: Wydawnictwo Lekarskie PZWL.

\section{Netografia:}

1. Bowen M., Plimpey L., Wtączanie uczniów z autyzmem w środowisko szkolne, https://polskiautyzm.pl/srodowisko-przyjazne-dzieciom-ze-spektrumautyzmu/,[dostęp 27.08.2020).

2. Wujec-Kaczmarek A., Uczeń autystyczny w zespole klasowym, https://www.slideshare.net/alicjawk/ucze-autystyczny-w-zespole-klasowym, [dostęp 5. 05.2020) 


\section{Streszczenie}

Czas pandemii to nieznana rzeczywistość, z którą musimy zmierzyć się wszyscy. Edukacja zdalna nie wpływa tylko i wyłącznie na stan naszej wiedzy. Szkoła jest miejscem, gdzie codziennie spotykają się rówieśnicy, którzy budują swoje relacje społeczne. Dla większości uczniów edukacja to przede wszystkim brak systematycznej nauki, co niesie ze sobą zaległości szkolne. Brak bezpośrednich relacji z rówieśnikami jak i nauczycielami wiąże się ze spadkiem własnej wartości. Dla dzieci ze spektrum autyzmu zarówno codzienna rutyna oraz przewidywalność tego, co będzie się działo, odgrywa istotną i ważną kwestię w ich rozwoju, edukacji oraz prawidłowym funkcjonowaniu w społeczeństwie. Wytrącenie z wypracowanego rytmu życia budzi lęk, frustrację, zaburza poczucie bezpieczeństwa. Zajęcia prowadzone przez ekran komputera to duże wyzwanie dla rodzica, który z dnia na dzień musi stać się nauczycielem, pracując ze swoim dzieckiem $\mathrm{w}$ domu na podstawie przekazanego materiału z lekcji.

Słowa kluczowe: pandemia, uczeń, szkoła, nauczyciel, rodzic, dom, spektrum autyzmu

\section{The situation of a pandemic and access to education for students with autism spectrum disorders}

\section{Summary}

The time of the pandemic is an unknown reality that we all have to face. Remote education does not only affect the state of our knowledge. School is a place where peers meet every day to build their social relationships. For most students, education is primarily the lack of systematic learning, which results in school backlogs. Lack of direct relationships with peers and teachers is associated with a decrease in self-worth. For children on the autism spectrum, both the daily routine and the predictability of what will happen play an important and important issue in their development, education and proper functioning in society. Throwing out of the established rhythm of life evokes fear, frustration, and disturbs the sense of security. Classes conducted through a computer screen are a big challenge for a parent who has to become a teacher overnight, working with his child at home on the basis of the lesson material provided.

Keywords: pandemic, student, school, teacher, parent, home, autism spectrum 